\section{AGATA NARUSZEWICZ}

Uniwersytet Jagielloński, Kraków, Polska

\section{EWA ZAJDLER}

Uniwersytet Jagielloński, Kraków, Polska

https://orcid.org/0000-0002-2640-9029
Copyright and License: Copyright by Instytut Języka Polskiego PAN, Kraków 2021. This article is published under the terms of the Creative Commons Attribution - NoDerivatives 4.0 International (CC BY- ND 4.0) License (https:// creativecommons.org/licenses/by-nd/4.0/legalcode.pl).

\title{
ŚRODKI JĘZYKOWE JAKO NARZĘDZIE NACECHOWANIA NIEFORMALNYCH WYPOWIEDZI KOBIET WE WSPÓŁCZESNYM JĘZYKU CHIŃSKIM
}

Słowa kluczowe: język chiński, socjolekt kobiet, zachowania językowe kobiet, sajiao.

\section{STRESZCZENIE}

Tematem artykułu jest korelacja między środkami językowymi w zasobach języka chińskiego a działaniami językowymi młodych kobiet realizowanymi na antenie rozrywkowego programu internetowego. Socjolekt kobiet i cechy stylu sajiao są analizowane na podstawie ich 1802 nieformalnych wypowiedzi zarejestrowanych w programie. W artykule zbadano, w jaki sposób cechy leksykalne i fonetyczne wyrażają kobiecość i jaki kształt nadają wypowiedziom kobiet pełniącym funkcję perswazyjną. Formalne środki językowe, którymi posługują się rodzime użytkowniczki języka chińskiego, komunikują grzeczność, emocje i łagodność, a jednocześnie potwierdzają ich pozycję podporządkowania w społeczeństwie. Badanie rozpoczyna się wprowadzeniem do pragmatyki kulturowej działań językowych i przechodzi do zarysowania aktualnej wiedzy na temat specyfiki języka chińskiego używanego przez Chinki. Z dotychczasowych dyskusji zostały - jako narzędzie analizy - wyprowadzone środki językowe. Omówiono poszczególne słowa i wyrażenia oraz cechy wymowy. Nie wszystkie cechy językowe języka mandaryńskiego omawiane we wcześniejszych badaniach znajdują potwierdzenie w badanych wypowiedziach. Te, które dodają wypowiedzi znacząco ekspresywnego charakteru i łagodności, dominują w studium nad stylem sajiao - cechami fonetycznymi i prozodycznymi typowymi dla dziecięcej formy perswazji. Analiza ilościowa i jakościowa wykazała wysoki stopień nacechowania wypowiedzi emocjami, niepewnością sądów (pozycjonującą nadawcę niżej od odbiorcy), a także artykulacją imitującą dziecięcą.

\section{WPROWADZENIE}

Praca koncentruje się na języku chińskim młodych rodzimych użytkowniczek, określanym $\mathrm{w}$ artykule jako socjolekt chińskich kobiet. W badaniu przyjęto, że realizowane na żywo widowisko artystyczno-rozrywkowe, w którym uczestniczą młode kobiety, 
pozwala zaobserwować werbalne reakcje mające wspólny mianownik stylu potocznego i wspólny repertuar środków językowych w zróżnicowanym stopniu eksploatowanych w idiolektach uczestniczek (zob. Jarosz 2013, 100; Bartwicka 2007, 15-16). „,[O] istocie socjolektów decyduje przede wszystkim leksyka (grupa społeczna tworzy własne zasoby wyrazów, pozostając przy składni potocznej lub literackiej)" (Grabias 2019, 109). Obserwacja frekwencyjności użycia wyrazów, fraz i konstrukcji decydujących o grzeczności językowej i ekspresywności oraz sposobu ich wymawiania pozwala określić styl językowy socjolektu kobiet. Uczestniczki reprezentują kręgi kobiet identyfikujących się z nimi przynajmniej pod względem wieku, systemu społecznych norm i wartości, oczekiwań wobec siebie i wobec pozostałych uczestniczek programu. Podstawową socjologiczną (choć też nieostrą) przesłanką do przywołania tu pojęcia socjolektu byłby młody wiek autorek wypowiedzi - i związana z wiekiem ekspresywność (zob. Grabias 2019, 107-108; Bartwicka 2007, 15). W tej konkretnej sytuacji programu widowiskowego uczestniczki stanowią grupę w miarę jednolitą, choć nie można już o niej powiedzieć, że trwałą (kryterium czasu to okres tworzenia programu). Współpracę w zespole realizującym projekt o charakterze medialnym należy tu uznać za czynnik warunkujący zachowania werbalne. Język grupy w ten sposób wyodrębnionej, dzielącej uwarunkowania społeczne i kulturowe, a w realizacji programu - także sytuacyjne i komunikacyjne, wykazuje cechy socjolektu.

Podstawą badania i źródłem materiału jest interakcja uczestników telewizyjnego programu, ,创造101” Chuàngzào101 (ang. „Produce 101”), emitowanego na chińskiej stronie internetowej Tencent Video (chiń. 腾讯视频 Téngxùn Shipinn) ${ }^{1}$. Materiał językowy stanowiący próbkę nieformalnych wypowiedzi kobiet został skonfrontowany z cechami chińskiego socjolektu kobiet, opisanymi w innych pracach. W wypowiedziach kobiet wyodrębniono formalne środki językowe współczesnego języka chińskiego, które decydują o specyfice chińskiego socjolektu kobiet. Uzyskano w ten sposób ilościowy i jakościowy obraz zjawisk leksykalnych, frazeologicznych, gramatycznych i fonetycznych składających się na cechy stylu potocznego z ukrytą treścią porządku społecznego, wyznaczającego pozycję kobiety.

Ze względu na spontaniczną, niewyreżyserowaną komunikację w kontekście rywalizacji o jak najszersze uznanie i jak najwyższą ocenę odbiorcy komunikatu (widzów) analizowane wypowiedzi wydają się reprezentatywne dla młodych kobiet. Istotne dla wyników analizy jest także założenie, że wypowiedzi nie realizują się w sferze prywatnej czy intymnej, ale mają charakter publiczny w porównywalnym kontekście. Nie da się jednak wykluczyć, że wstępna selekcja uczestniczek zakładała pewne indywidualne cechy na potrzeby realizacji programu telewizyjnego.

\footnotetext{
${ }^{1}$ Zob. Platforma Téngxùn shìpín [Tencent Video]. https://www.youtube.com/channel/UCQatgKoA7lylp_UzvsLCgcw (15 lutego 2021).
} 


\section{PRAGMATYKA - ZACHOWANIA JĘZYKOWE UWARUNKOWANE KULTURĄ}

Różnice w stylu wypowiedzi wynikają z odmiennych ról społecznych, z miejsca wyznaczonego przez tradycję danego kręgu kulturowego, a także z celu interakcji między uczestnikami komunikacji.

Codzienna komunikacja językowa zachodzi w powtarzających się sytuacjach stwarzanych przez życie społeczne. [...] Stereotypowe zachowania komunikacyjne, uwarunkowane sytuacjami, w jakich zachodzą, bywają nazywane rozmaicie: wariantami sytuacyjnymi, funkcjonalnymi, nadbudowanymi, wreszcie rejestrami lub stylami (Grabias 2019, 106).

W akcie komunikacyjnym nadawca kreuje własny wizerunek. Zasady grzeczności i taktu wymagają takiego zachowania językowego, którego forma jest akceptowalna, a dla danej sytuacji wręcz oczekiwana przez odbiorców komunikatu (Awdiejew i Habrajska 2006). Brown i Levinson (1988, 61-70) wpisują strategię grzeczności w interakcji społecznej w uniwersalną koncepcję zachowania lub utraty twarzy, pierwotnie wywodzącą się ze społecznego szacunku i norm zachowań w kręgu kultury chińskiej (zob. Hu 1944, Niewdana 2011). Rozróżniają twarz pozytywną i negatywną, na podstawie czego definiują grzeczność pozytywną i negatywną. Grzeczność pozytywna polega na współpracy, na sympatii wobec odbiorcy, i na podkreślaniu podobieństw między stronami aktu komunikacyjnego, a przy tym ma charakter bezpośredni. Grzeczność negatywna odwołuje się do zachowania dystansu do rozmówcy m.in. przez częste przepraszanie czy wtrącanie fraz zmniejszających siłę własnej wypowiedzi. Wielu badaczy uważa, że koncepcja Brown i Levinsona (1988) nie zgadza się z chińską koncepcją „twarzy”: twierdzi, że grzeczność uznana przez oboje naukowców za negatywną jest w istocie cechą chińskiej kultury i wcale nie burzy harmonii w społeczeństwie (Lin 2005, 41). Wręcz przeciwnie - rytualizm, wynikający z konfucjańskiego porządku społecznego, wiąże grzeczność (podobnie jak inne wartości społeczne) z obyczajem i etykietą (禮 $l i$ ) (Wesołowski 2011, 180), a grzecznościowe zachowania językowe, unikające bezpośredniej konfrontacji (otwartego konfliktu) nadawcy i odbiorcy, mają na celu utrzymanie ładu i dobrych relacji międzyludzkich.

Niezależnie od języka i kultury analiza aktów mowy wykazuje, że bez względu na kontekst kulturowy kobiety są w realizacji tych aktów bardziej uprzejme i grzeczne niż mężczyźni Lakoff (1973: 56). Podczas gdy interpretacja bezpośredniego aktu mowy odwołuje się do jednoznaczności treści, interpretacja pośredniego aktu mowy wymaga rozpatrzenia danej wypowiedzi w kontekście i ustalenia celu komunikatu. Wypowiedzenie w pośrednim akcie mowy niesie znaczenie szersze niż treść wyrażenia wynikająca z systemu języka (nie chodzi tu o metafory, wypowiedzi ironiczne czy wyrażenia idiomatyczne). Dystans do zamierzonego oddziaływania na odbiorcę komunikatu, zachowany w takim działaniu językowym, nie tylko pozostawia mu przestrzeń do decyzji, ale wręcz włącza go w układ nadawczo-odbiorczy, wymagający samodzielnej interpretacji. Z kolei nadawcy pozostawia bezpieczną możliwość wycofania się (Awdiejew i Habrajska 2006; Wiertlewski 1995, 34). Grzeczność realizowana w akcie pośrednim osłabia siłę 
wypowiedzi i jej intencję, zachowuje przy tym zdolność oddziaływania na odbiorcę. Językowe zachowania komunikacyjne kobiet w chińskim kręgu kulturowym cechuje styl wypowiedzi sygnalizujący niepewność własnego stanowiska, niesamodzielność, a nawet pewną dziecinność. Retoryka perswazji ukrytej za grzecznym zajmowaniem wskazanego „niższego” miejsca w porządku społecznym i jakby dziecięcą bezradnością może jednak stanowić strategię ukierunkowaną na osiągnięcie celu odpowiedzi lub działania rozmówcy. Kobiety w społeczeństwie silnie uwarunkowanym kulturowo muszą w działaniu językowym odwoływać się do skutecznych środków językowych, kodujących intencję i gwarantujących oddziaływanie na odbiorcę.

Czynnikami, które wpływają na wybór strategii i taktyki wypowiedzi, są dyspozycje psychiczne, kompetencja językowa mówiącego, temat rozmowy, role społeczne uczestników dialogu, ich wzajemne stosunki, wymogi etykiety językowej (Bartwicka 2007, 16).

Wśród podejmowanych tematów z zakresu pragmatyki języka i komunikacji w języku chińskim wyróżnia się grzeczność językowa. W ocenie Shi (1984, 222-223) młode kobiety częściej prawią komplementy, a gdy dostają komplement, grzecznie zaprzeczają. Wyrażanie prośby porównał w ankietowym badaniu Ding (2002, 46-50). Wśród uczestników badania (30 kobiet i 30 mężczyzn) kobiety użyły więcej zwrotów grzecznościowych, dzięki czemu nadały prośbom bardziej pośredni charakter, niż zrobili to mężczyźni. Lin (2005, 118, 169-170) zgadza się z tezą Lakoffa (1973), że to kobiety częściej posługują się grzecznością negatywną. Potwierdza to wynikami badań form grzecznościowych używanych przez chińskich sprzedawców, zgodnie z którymi mniej stanowcze okazują się wypowiedzi ekspedientek ${ }^{2}$. Zdaniem Pan $(2015,79)$ oznaką grzeczności kobiet jest m.in. zadawanie licznych pytań jako przejaw troski o to, aby konwersacja przebiegała płynnie i była podtrzymywana. Bartwicka (2007, 20-21) wyróżniła tu specyficzny rodzaj rozmowy, który nazwała gadaniem:

\footnotetext{
Gadanie wyróżnia ważna cecha - jest to akt komunikacji realizowany dla samej komunikacji. To rozmowa lekka, swobodna, często powierzchowna, rozmówcy zazwyczaj nie wgłębiają się w istotę poruszonych spraw, żartują, łatwo przeskakuję z tematu na temat, przy czym nadawca często nie wie, o czym będzie mówił za chwilę. [...] Gadanie jako gatunek mowy cechuje bogactwo słownictwa ekspresywnego. Nierzadko w niedużym tekście występuje nagromadzenie różnorodnych wyrazistych jednostek leksykalnych np. frazeologizmów, okazjonalizmów, epitetów, metafor, porównań. Język kobiecy cechuje duża koncentracja wszelkich tego typu ozdobników. Jednym z ważnych wyróżników gadania jest stosowanie przez kobiety przerywników niezwiązanych z tematem rozmowy.
}

Widowisko rozrywkowe jest przykładem nagromadzenia takich rozmów. Wypowiedzi integrują w nim nie tylko uczestników programu, bezpośrednio zaangażowanych w dialogi, lecz także widzów, utożsamiających się z wydarzeniem, uczestnikami i sytuacjami komunikacyjnymi.

\footnotetext{
${ }^{2} \mathrm{O}$ łagodności zdecydowały cztery razy częściej użyte partykuły modalne.
} 


\section{CHIŃSKI SOCJOLEKT KOBIET I ŚRODKI JEGO REALIZACJI}

Większość analiz cech i form językowych w języku chińskim kobiet polegała na obserwacjach lub badaniach ankietowych przeprowadzanych w zróżnicowanych warunkach. Dlatego trudno porównać te wyniki. Można jednak wyłonić z nich środki językowe.

Wang $(2013,40)$ podkreśla, że chińska kobieta, nawet zdenerwowana, nie używa przekleństw. Zdanie to podziela Shi $(1984,219)$ - przyznaje, że kobiety przeklinają rzadziej niż mężczyźni. Aby wyrazić negatywne emocje, używają fraz, które zastępują przekleństwa (np. 讨厌 tăoyàn 'irytujące', 真是的 zhênshide 'no, naprawdę', 我的妈呀 wǒdemāya 'o mamo', 去你的 qùnǔde 'idź sobie'). Trudno zakwalifikować te wyrażenia i zwroty ściśle do eufemizmów, co nie zmienia faktu, ze strategią grzecznościową jest używanie eufemizmów tam, gdzie podejmowany jest temat w obszarze kulturowego tabu. Sun $(2012,52)$ dzieli eufemizmy, którymi w języku chińskim posługują się kobiety, na trzy kategorie, dotyczące: 1. spraw damsko-męskich (云雨 yúnyŭ 'chmury i deszcz', 房事 fángshì 'sprawy pokojowe'), 2. części ciała i fizjologii (我去一下 wǒ qù yīxià 'pójdę na chwilę') oraz 3. ciąży (我有了 wǒ yǒule 'dostałam', 大肚子了 dàdùzile 'powiększył się brzuch'), aborcji (计划了 jìhuàle 'zaplanowane', 采取措施 căiqǔ cuòshī 'podjąć środki'), menstruacji (例假 lì jiă 'wakacje', 倒霉 dăoméi 'pech'). Eufemiczne może być także mówienie o kimś. Ankietowe badanie przeprowadzone na grupie 102 nankińskich studentów (51 mężczyzn i 51 kobiet) pokazało, że kobiety są bardziej skłonne do używania eufemizmów, aby okazać delikatność, np. żeby opisać tęgą osobę, stosują określenia: 不瘦 bú shòu 'nieszczupły', 丰满 fēngmăn 'obfity' (Jiang 2007, 58).

Farris (1991, 203-204) przeprowadziła obserwacje i analizę zachowań dzieci z tajwańskiego przedszkola. Większość badanych grup dzieci była jednorodna pod względem płci (grupy chłopców i dziewczynek). Gdy wśród chłopców pojawiał się konflikt, okazywali się oni bardziej skłonni do użycia przekleństw, mówili wprost, co myślą, dużo krzyczeli. Naśladowali mowę mężczyzn: stosowali agresję słowną i usiłowali dominować. W przeciwieństwie do dziewczynek posługiwali się słowami dźwiękonaśladowczymi. Dziewczynki natomiast brały udział w konflikcie w sposób mniej bezpośredni, bardziej zależało im na utrzymaniu relacji społecznych i harmonii w grupie. Były cichsze, mniej bezpośrednie. Na podstawie tych obserwacji Farris zgodziła się z teorią genderlektów, sformułowaną przez Tannen (1999), która przypisuje mężczyznom i kobietom ,inne światy” i związane z nimi inne cele komunikacji językowej już na etapie ich dzieciństwa: mężczyznom - przekazywanie informacji, kobietom - tworzenie więzi, współpracę, wyszukiwanie podobieństw i dążenie do kompromisu (Farris 1991, 208-215; Tannen 1999, 36, 39, 73).

Ciekawe wnioski z obserwacji i pracy terenowej w Tajpej i Szanghaju zawiera praca Yueh (2012) oraz - oparta na badaniach ankietowych przeprowadzonych na tym samym terenie - publikacja Hardeman (2013). Uwagę badaczy przyciągnął styl określany mianem sajiao, popularny wśród kobiet na Tajwanie, czasem niesłusznie tylko im przypisany. Ten termin (chiń. 撒娇 sājiāo o konstrukcji VO: 撒 $s \bar{a}$ 'rozpraszać, 
roztaczać, rzucać, 娇 jiāo 'urok, kobiecość') jest stosowany na określenie „kobiecego” stylu komunikacji, przypominającego zachowanie dziecka, kojarzonego z mówieniem ,uroczo i słodko”, z zamiarem oddziaływania na rozmówcę (Hardeman 2013, 33; Yueh 2012, 17). Jako forma perswazji sajiao na poziomie leksykalnym polega na bezpośrednim wyrażaniu swojej opinii lub żądania czegoś („chcę więcej”, „nie podoba mi się to"). Osoba używająca sajiao stara się być postrzegana jako ktoś bezbronny, potrzebujący pomocy, żeby w ten sposób osiągnąć swój cel (Hardeman 2013, 165; Yueh 2013, 161). Nasuwa się pytanie, czy sama bezradność, nakładająca się na bezpośrednio zwerbalizowane oczekiwanie, nie czyni działania językowego pośrednim, skoro w układzie nadawczo-odbiorczym interpretację i odpowiedź na ukrytą perswazję przerzuca na odbiorcę komunikatu. Materiał językowy opisany przez Yueh (2012) pod kątem sajiao to dialogi przeprowadzone między zakochanymi, rodzicami i dziećmi czy sprzedawcami i klientami oraz codzienne formy grzecznościowe z tajwańskiej telewizji. Zdaniem Yueh (2012, 157-189) odbiorcy tak wyrażonego komunikatu trudniej jest odmówić, być złym na nadawcę czy się na niego obrazić. Używanie sajiao może też być formą unikania odpowiedzi na zadane pytanie.

Lin (2005, 119-120) utożsamia sajiao z grzecznością negatywną z powodu wysokiego rejestru dźwięków mowy, co z kolei Brown i Levinson (1988) łączą z mechanizmem obronnym osoby dorosłej, gdy naśladuje ona sposób mówienia małego dziecka. Prozodię kobiet cechuje intonacja wznosząca, która często okazuje się skorelowana ze zdaniową partykułą modalną (Shi 1984, 224-225; Pan 2015, 79; Chan 1998, 43-44; Chao 1968, 68). Do zestawu narzędzi językowych sajiao należy zatem fonetyka artykulacyjna (tu również związana z wymową tonalną) i prozodia. Yueh $(2012,138,185-186)$ dodaje spostrzeżenie o niedbałej wymowie powodującej utratę (synkopę) lub/i substytucję głosek, która może występować razem z wysokim rejestrem mowy - dziecięcym głosem (chiń. 娃娃音 wáwayīn).

Kolejną cechą artykulacyjną mowy kobiet jest nienaturalna wymowa [tc], [tch], [6] (chiń. 女国音 nüguóyinn). To zjawisko w literaturze przedmiotu nazywa się także 舌位前化 shéwèi qiánhuà lub 前移现象 qiányí xiànxiàng (dosł. 'przeniesieniem języka do przodu’) (Cao 1986, 31). Ta maniera polega na wymawianiu spółgłosek przedniopodniebiennych [t6], [tch], [6] tak, jak wymawia się spółgłoski przedniojęzykowo-zębowe [ts], [tsh], [s] (Chan i Lin 2019, 169). Zdaniem Cao $(1986,31)$ początki pojawiania się takiej artykulacji w dialekcie pekińskim to lata 20. i 30. XX wieku, przy czym powody trudno ustalić. Mógł to być wpływ dialektów południowych (zwłaszcza tych z Jiangsu i Szanghaju), opery pekińskiej, w której występuje „przeniesienie języka do przodu”, lub ówczesnej estetyki. Zhao $(2003,117)$ ogranicza zasięg tej maniery głównie do Pekinu i egzemplifikuje ją wypowiedziami w stacji CCTV (np. wymawiane w pierwszym tonie 今 ([tsin] zamiast [t6in]). Badacze zgodnie twierdzą, że ta maniera pojawia się głównie u młodych dziewcząt, uczennic szkół średnich i studentek, choć może też pojawiać się czasowo u chłopców w wieku 14-15 lat (Cao 1986; Sun 2012; Zhao 2003; Chan i Lin 2019). 
Inną manierą jest używanie wariantu [v] w miejsce nagłosu pustego w kombinacji ${ }^{3}$ z wygłosem rozpoczynającym się od niesylabicznej półsamogłoski [u] (np. wymawiane w drugim tonie 蚊 ([wen] > [ven]) (Tseng 2008, 5, 7-11). Przesunięcie samogłoski [u] wymawianej jako spółgłoska półotwarta wargowo-miękkopodniebienna [w] w kierunku wymowy wargowo-zębowej daje efekt nagłosu [v] w różnym stopniu zbliżonego do spółgłoski szczelinowej wargowo-zębowej dźwięcznej [v] (w zapisie pinyin oznaczonego literą ,w”, np. wén). To zjawisko pojawia się także w dialekcie pekińskim i postrzegane jest w realizacji standardowego języka chińskiego w Chinach jako bardziej kobiece. Jak podaje Chan $(1998,38)$, wariant [v] rozpowszechnił się w innych regionach Chin, a jedyną cezurą prawdopodobną i do określenia jest przełom lat 70. i 80. XX wieku. Omawianego wariantu używają prezenterki telewizyjne w Chinach i - rzadziej - na Tajwanie ${ }^{4}$.

Na pograniczu fonetyki i morfologii w wersji kontynentalnej języka chińskiego jest eryzacja (dodanie do sylaby sufiksu - 兒 er), które w mowie kobiet, wraz z przymiotnikiem 小 xiăo 'mały', użytym prefiksalnie, lub bez tego przymiotnika, może mieć deminutywny charakter. Za zdrobnienia uważa się wyrazy 小曲儿 xiăoqǔr 'piosenka', 麻花儿 máhuār 'rodzaj ciasta', 手绢儿 shǒujuànr 'chusteczka', ale też przydomki, które kobiety nadają swoim koleżankom (宝贝儿 băobèir, 乘乘儿 guāiguāir 'skarb’ / 'maleństwo') (Wang 2013: 41).

Jedną z pierwszych prac na temat chińskiego socjolektu kobiet napisała Shi (1984). Zajęła się komunikowaniem się w kontekście społecznym i zagadnieniami fonetycznymi, leksykalnymi oraz gramatycznymi. Zwróciła uwagę m.in. na powtarzanie wyrazów i zwrotów jako nawyk kobiet mniej pewnych zarówno siebie, jak i tego, co mówią. Badacze zauważają wśród kobiet również powszechność użycia partykuł modalnych pełniących funkcję ekspresywną, a wypowiedziom z ich użyciem przypisują - tak charakterystyczny dla chińskich kobiet - brak asertywności. Należy tu przypomnieć, że zdaniowe partykuły modalne sprzyjają generowaniu intonacji wznoszącej w stylu sajiao. Badania Ma (2009) dowodzą, że partykuły modalne używane przez kobiety są bardziej różnorodne. U mężczyzn pojawiają się partykuły 啊 $a$, 呀 $y a$, 了 le, a u kobiet $a$, 呀 ya, 哟 yo, 咧 lie, 噢 $o$, 啰 luo, 嘛 $m a$, 嘢 ye, 啦 la, 吧 $b a^{5}$ oraz 呢 ne (Ma (2009, 59; Chan i Lin 2019, 169; Wamsley 2019, 17).

Qi i Zhang (2009, 64-66) przeprowadzili badania wykrzykników popularnych wśród kobiet i mężczyzn. Analizie poddali dialogi ze scenariusza serialu pt. 空镜子 Kōng jìngzi (pol. „Puste lustro”). Mimo że kobiety używały mniej wykrzykników niż mężczyźni

\footnotetext{
${ }^{3}$ Chan $(1998,38)$ mówi o niesylabotwórczej i sylabotwórczej półsamogłosce [u] bez podania przykładów. Tseng (2008) potwierdza to zjawisko jedynie dla niesylabotwórczej półsamogłoski [u] i podaje przykłady.

${ }^{4}$ Chan (1998) pisze o oczekiwaniach wobec prezenterek-stażystek w tajwańskiej telewizji TTV w roku 1989. Musiały one z prowadzącą zajęcia ćwiczyć wymowę [v] w wyrazach 一万 yīwàn 'dziesięć tysięcy' czy 新闻 xīnwén 'wiadomości', co świadczy o braku tej maniery. Wśród mężczyzn występuje ona tylko w Chinach.

${ }^{5}$ Tej wielokategorialnej partykuły używają również mężczyźni, jednak głównie do konstruowania pytań (Sun 2012, 51).
} 
(odpowiednio: 5,8\% w wypowiedziach kobiet i 7,3\% w wypowiedziach mężczyzn), okazało się, że wykrzykniki używane przez kobiety są bardziej różnorodne. Zarówno mężczyźni, jak i kobiety używali wykrzykników 啊 $a$, 哟 yō, 哼 hēng, 嘿 heei, 哦 $o$,

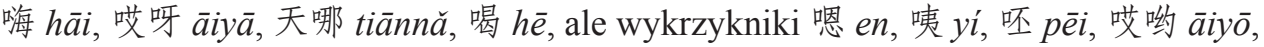
妈呀 $m \bar{a} y a$, 哇 $w \bar{a}$, 哎哟 $\bar{a} i y \bar{o}$, 嘛 $m a$, 啦 $l a$, 耶 $y \bar{e}$, 呀 $y a$ i 噢 $\bar{o}$ pojawiały się tylko w wypowiedziach kobiet (Qi i Zhang 2009, 64-66; Shi 1984, 220-221).

Zeng (2007, 65-68) zbadał użycie przysłówków stopnia w języku chińskim w zależności od płci. Źródłem materiału badawczego były trzy programy telewizyjne, a badanymi - 27 mężczyzn i 27 kobiet. Analiza wykazała, że kobiety częściej używały przysłówków stopnia (比较 bǔjiào 'dosyć', 有点 yǒudiăn 'trochę', 非常 fêicháng 'bardzo', 特别 tèbié i 尤其 yóuqi 'wyjątkowo', 最 zuì 'najbardziej', 可 kě oraz十分 shífén 'bardzo', 真 zhēn 'naprawdę' ${ }^{6}$ ) niż mężczyźni. Wyjątek stanowiło użycie przez mężczyzn tych przysłówków stopnia, które Zeng uznaje za dialektalne (忒 tè 'zbyt', 蛮 mán 'dość / stosunkowo'). Te same badania pokazały również, że kobiety częściej posługują się reduplikacją przysłówków w strukturach $\mathrm{ABx} \mathrm{ABx}^{8}$ (powtórzenie całej frazy: 非常好非常好 fêicháng hăo féicháng hăo 'bardzo dobrze, bardzo dobrze') i ABABx (powtórzenie jedynie przysłówka: 非常非常好 fêicháng fēicháng hăo 'bardzo bardzo dobry'). Pierwszej konstrukcji użyto w tym badaniu 18 razy, w tym 15 razy użyły jej kobiety, natomiast drugiej - 34 razy, z czego: kobiety - 25 razy, mężczyźni - 9 razy.

Badania Liu, przeprowadzone na podstawie wypowiedzi 28 mężczyzn i 29 kobiet w tajwańskich programach telewizyjnych, ujawniły, że końcówki pytające w formie pytań alternatywnych (对不对 dui bú dui 'prawda?,'是不是 shì bú shì lub 有没有 yǒu méi yǒu 'tak czy nie?', 好不好 hăo bù hăo 'dobrze?') i partykuły pytajnej 吗 ma (不是吗 bú shì ma 'czyż nie?', 可以吗 kěyı̌ ma 'można?', 不可以吗 bù kěyı̌ ma 'nie można?', 好吗 hăo ma 'dobrze?', 是吗 shì ma 'czyż nie?') były tak samo często używane przez mężczyzn, jak i przez kobiety (Liu 2005, 44-49). Liu nie stwierdziła również, aby kobiety częściej niż mężczyźni używały zaimków wzmacniających (如此 rúč́ ' $\mathrm{w}$ ten sposób', 这么 zhème lub 那么 nàme ‘tak bardzo') (2005, 50-53). Nie stwierdzono różnic w używaniu pustych przymiotników' (可爱的 kě'ài de 'uroczy', 吸引人的 xīyinnrén de 'atrakcyjny', 迷人的 mírén de 'czarujący', 有鬼米力的 yǒumèili de 'uroczy', 甜美的

\footnotetext{
${ }^{6} \mathrm{O}$ ile 真 zhēn 'naprawdę' jest przysłówkiem występującym z przymiotnikiem, w konstrukcji 真的 zhēnde 'naprawdę' staje się samodzielnym wyrażeniem nacechowanym emocjami i przekonywaniem o wiarygodności.

${ }^{7}$ Reduplikacja wewnątrzwyrazowa i składniowa jest w języku chińskim zjawiskiem powszechnym; realizowana jest według struktur 人人 rén rén 'każdy', 想想 xiăngxiang ‘pomyśleć trochę’, czy 高高兴兴地 gāogāoxingxìng de 'radośnie' (prewerbalna konstrukcja przysłówkowa). Zob. Chao 1968, 118-225; Chen i in. 1992, 218-220; Li i Thompson 1989, 29.

${ }^{8}$ Gdzie x oznacza przymiotnik intensyfikowany przysłówkiem dwusylabowym AB.

${ }^{9}$ Przymiotniki puste nazywają cechę tak, że stawiają na ekspresywność wypowiedzi, a nie na fakt wskazania przymiotu, przyjmują przysłówek intensywności (好 hăo i 真 zhēn 'ależ’ / ‘jak bardzo') np. w 好漂亮 hăo piàoliang 'ale ładny', 真好吃 zhên hăochī 'naprawdę smaczny'. W ograniczonych przypadkach przyjmują przymiotnik w funkcji postpozycyjnego dopełnienia komplementywnego stopnia/intensywności (极了 jíle 'ekstremalny' / ‘bardzo skrajnie', 死了 sìle ‘śmiertelny' / 'strasznie, potwornie') 棒极了 bàng jíle 'ale super', 高兴死了 gāoxing sìle 'strasznie wesoły'). Zob. Shi 1984, 219; Liu i in. 1996, 335-336.
} 
tiánměi de 'słodki'). Potwierdziła się natomiast teza, że kobiety częściej posługują się wtrąceniami (我觉得 wǒ juédé 'uważam, że', 我认为 wǒ rènwéi 'uważam, że', 我想 wǒ xiăng 'myślę, że', 你知道 nǐ zhìdào 'wiesz') i przysłówkami (有点 yǒudiăn lub 有一点 yǒu yīdiăn 'trochę'), które osłabiają znaczenie i siłę wypowiedzi, w wyniku czego stają się formą grzeczności negatywnej (Liu 2005, 40). W myśl ustaleń poczynionych przez Pan $(2015,79)$ i Shi $(1984,222-223)$ można poszerzyć listę wtrąceń o 你知道的 nĭ zhīdào de 'wiesz, że', 我想 wǒ xiǎng 'myślę, że' 很有可能 hěn yǒu kěnéng 'najprawdopodobniej', 我猜 wǒ cāi 'zgaduję, że', 大概 dàgài 'mniej więcej', 可能 kěnéng 'chyba', 好像 hăoxiàng 'wydaje mi się, że'. Liu (2005, 36-37) wskazała także na podstawowe formy grzecznościowe wyrażone czasownikiem lub frazą (请 q̌ng 'proszę', 你可不可以 nǐ kěbù kěyı̌ i 你能不能 nǐ néng bù néng 'czy mógłbyś?’, 你介不介意 nì jiè bù jièyì 'czy masz coś przeciwko temu?').

Shi (1984, 219), Farris (1988, 291) i Chan (1998, 43) zwróciły uwagę na umniejszanie roli własnej osoby. Stwierdziły, że kobiety mówią o sobie, używając zaimka pierwszoosobowego 我 wǒ rzadziej niż mężczyźni, ponieważ w zamian używają zaimka 人家 rénjia, który można by przełożyć na zaimek nieokreślony 'ktoś'.

\section{KRYTERIA ANALIZY}

Przegląd badań nad chińskim socjolektem kobiet dowodzi dużego zróżnicowania pytań badawczych, badanych zagadnień i aspektów użycia języka. Ze względu na typ badań (przeważają obserwacja i badania ankietowe) obejmujących niewielkie grupy badawcze, a także z uwagi na nie zawsze precyzyjnie podane szczegóły procedury badawczej, są to raczej tylko pewne spostrzeżenia i punkty odniesienia, dopiero wyznaczające kierunek dalszych badań i kolejnych analiz. Materiał językowy wypowiedzi kobiet poddano tu analizie ilościowej i jakościowej pod kątem cech kobiecego socjolektu, wskazanych we wcześniejszych badaniach. Środki językowe dostępne w zasobach leksykalnych i gramatycznych współczesnego języka chińskiego, przypisywane cechom kobiecej wypowiedzi w nieformalnym kontekście komunikacji, uporządkowano według kryterium wpływu na grzeczność negatywną, pod względem ekspresywności wypowiedzi oraz z uwagi na warstwę dźwiękową mowy. Pozwoliło to wskazać w tych trzech kategoriach wyrazy (według klasy i/lub funkcji w zdaniu), konstrukcje gramatyczne oraz zjawiska w języku, obecne lub wykluczone w badanych komunikatach kobiet. W analizie ilościowej zwrócono uwagę na ich reprezentatywność, a w jakościowej - na funkcję pełnioną w akcie komunikacji.

$\rightarrow$ Formy wyrazu nadające wypowiedzi charakter grzeczności negatywnej:

- brak form grzecznościowych (wyrazów/fraz),

- wtrącenia (wyrazy wyrażające niepewność sądów),

- przysłówki osłabiające znaczenie (有点 yǒudiăn lub 有一点 yǒu yīdiăn 'trochę'),

- końcówki pytające,

- zdaniowe partykuły modalne podkreślające niepewność sądów i pozostawienie odbiorcy możliwości interpretacji, 
- komplementowanie i odrzucanie komplementów,

- zaimek umniejszający rolę własnej osoby.

$\rightarrow$ Formy wyrazu nadająca wypowiedzi łagodny i emocjonalny charakter:

- brak przekleństw, eufemizmy,

- puste przymiotniki (wyrażające ekstremalne emocje i oceny),

- zaimki wzmacniające,

- przysłówki stopnia,

- wykrzykniki,

- reduplikacja,

- deminutywy,

- zapewnienie jako uwiarygodnienie wypowiedzi.

$\rightarrow$ Fonetyka i prozodia:

- artykulacja dźwięków i intonacja -

- maniera 女国音 nüguóyīn - spółgłoski przedniojęzykowo-zębowe [ts], [tsh], [s],

- maniera - wariant [v],

- maniera 娃娃音 wáwayīn 'głosem niemowlęcia' (wysoki rejestr - styl sajiao),

- przedłużony (dłużej wymawiany) wygłos,

- synkopa - utrata samogłoski (styl sajiao),

- intonacja wznosząca (styl sajiao),

- artykulacja imitująca dziecko (styl sajiao),

- intonacja wznosząca skorelowana z użyciem partykuł modalnych (styl sajiao).

ŚRODKI JĘZYKOWE W WYPOWIEDZIACH UCZESTNICZEK PROGRAMU ,创造101” (ANG. „PRODUCE 101”)

\section{Źródło materiału językowego}

Analizę sposobu realizacji socjolektu chińskich kobiet przeprowadzono na korpusie wypowiedzi z chińskiego telewizyjnego programu artystyczno-rozrywkowego, ,创造101" (Chuàngzào101 „Produce 101”), wyprodukowanego przez firmę Tencent (na licencji koreańskiej wytwórni CJ E\&M). Program nagrywano przez trzy miesiące, a emitowano przez dwa (21.04.2018 - 23.06.2018). Wzięło w nim udział 101 dziewcząt i młodych kobiet w wieku od 16 do 28 lat. Widzowie mogli głosować na - ich zdaniem - najbardziej utalentowane uczestniczki programu.

Łączny czas wszystkich analizowanych odcinków programu wyniósł 26 godzin, 52 minuty i 10 sekund (zob. tabela 4). Na potrzeby gromadzonego materiału językowego poddano transkrypcji wypowiedzi kobiet w tym programie. Przyjęto następujące kryteria: 
- $\quad$ wypowiedź przyporządkowana konkretnej uczestniczce programu,

- $\quad$ wypowiedź wykazująca którąkolwiek z omówionych wyżej cech uznanych przez badaczy za charakterystyczną dla socjolektu chińskich kobiet.

\section{Analiza ilościowa i jakościowa wypowiedzi}

Zgromadzono 1802 nacechowane wypowiedzi 96 uczestniczek (5 nie zabrało w ogóle głosu). W wielu wypowiedziach pojawiło się kilka środków językowych uznanych za typowe dla kobiet. Liczba wypowiedzi uczestniczki zależała od umiejętności wchodzenia w interakcję i czasu antenowego (im większa przychylność publiczności i wyższy wynik głosowania, tym dłużej uczestniczka pozostawała w programie). Najwyższe takie liczby oscylują wokół 100. Niżej przedstawiono analizę ilościową i jakościową wypowiedzi trzech najbardziej aktywnych uczestniczek, a zatem - analizę najobszerniej reprezentowanego materiału językowego idiolektów, w odniesieniu do całego zebranego materiału. Wypowiedzi tych uczestniczek jest ${ }^{10} 103$ (A), 102 (B) oraz 95 (C). Szczegółowy rozkład zastosowanych przez nie środków językowych przedstawiają tabele 1, 2 oraz 3.

Dystans do rozmówcy, stanowiący element grzeczności negatywnej, pomagają zachować odpowiednie środki leksykalne i konstrukcje. W badanym materiale językowym zaobserwowano to zjawisko 1057 razy. Wtrącenia pojawiają się 388 razy, a partykuły modalne - 589. Przysłówki osłabiające znaczenie mają 38 wystąpień, a tylko 24 to komplementy lub ich odrzucenie, z kolei 18 wypowiedzi zawiera końcówki pytające w formie pytań alternatywnych, a frazy wyrażające prośbę/pytanie o zgodę mają 14 wystąpień. Zaimek osobowy 人家 rénjia nie został przez uczestniczki użyty ani razu.

Wypowiedzi (A) zawierają 75 wyrażeń kojarzonych z grzecznością negatywną. Tylko raz użyty został podstawowy, neutralny pod tym względem, jeden ze zwrotów grzecznościowych 'prosić', natomiast aż 31 razy pojawiają się wtrącenia osłabiające własną pozycję i przekonanie o swojej racji. Równie powszechne (37 razy) okazuje się użycie partykuł modalnych wskazujących na brak stanowczości i asertywności. Komplementowanie innych i odrzucanie komplementów w wypadku uczestniczki (A) to zaledwie trzy wystąpienia, a przysłówki osłabiające znaczenie i końcówki pytające w formie pytań alternatywnych wyrażających potrzebę akceptacji drugiej strony pojawiają się dwa razy. Podobną do (A) proporcję środków językowych realizujących grzeczność negatywną widać u uczestniczki (B) - 54 i (C) - 42. Wtrącenia to - odpowiednio - 15 i 10 użyć, a partykuły modalne potwierdzono w 34 i 29 użyciach łagodzących stanowczość wypowiedzi. To te dwa narzędzia językowe decydują w analizowanych wypowiedziach kobiet o przyjmowanej przez nie pozycji w relacji do odbiorcy komunikatu. Podobnie jak u uczestniczki (A), nieliczne są wypowiedzi pozostałych dwóch kobiet związane z komplementowaniem - odpowiednio: dwie (B) i jedna (C). Podobnie jak w wypowiedziach uczestniczki (A), zwrot grzecznościowy 'prosić' nie ma znaczenia dla grzeczności

\footnotetext{
${ }^{10} \mathrm{~W}$ celu anonimizacji danych uczestniczki oznaczono w pracy symbolami (A), (B) i (C).
} 
nadawców (B) i (C): jedynie uczestniczka (C) użyła go raz. Przysłówki osłabiające znaczenie z reprezentacją dwu- (B) i jednokrotnego $(\mathrm{C})$ użycia oraz końcówki pytające w formie pytań alternatywnych, które pojawiły się jeden raz u obu kobiet, nieznacznie wzbogacają formy grzeczności negatywnej.

Tabela 1

Środki językowe w wyrażaniu grzeczności negatywnej

\begin{tabular}{|c|c|c|c|c|c|c|c|c|}
\hline \multirow{2}{*}{$\begin{array}{l}\text { Kod } \\
\text { uczest- } \\
\text { niczki }\end{array}$} & \multirow{2}{*}{$\begin{array}{l}\text { Liczba } \\
\text { wypo- } \\
\text { wiedzi }\end{array}$} & \multirow{2}{*}{$\begin{array}{l}\text { Leksykal- } \\
\text { ne formy } \\
\text { grzeczno- } \\
\text { ściowe }\end{array}$} & \multicolumn{6}{|c|}{ Grzeczność negatywna - obserwacje } \\
\hline & & & $\begin{array}{l}\text { wtrą- } \\
\text { cenia }\end{array}$ & $\begin{array}{l}\text { przysłówki } \\
\text { osłabiające } \\
\text { znaczenie }\end{array}$ & $\begin{array}{l}\text { końcówki } \\
\text { pytające }\end{array}$ & $\begin{array}{l}\text { partykuły } \\
\text { modalne }\end{array}$ & $\begin{array}{l}\text { kom- } \\
\text { plemen- } \\
\text { towanie }\end{array}$ & $\begin{array}{l}\text { zaimek } \\
\text { umniej- } \\
\text { szający }\end{array}$ \\
\hline (A) & 103 & 1 & 31 & 2 & 2 & 37 & 3 & 0 \\
\hline (B) & 102 & 0 & 15 & 2 & 1 & 34 & 2 & 0 \\
\hline (C) & 95 & 1 & 10 & 1 & 1 & 29 & 1 & 0 \\
\hline $\begin{array}{l}93 \\
\text { pozostałe } \\
\text { uczest- } \\
\text { niczki }\end{array}$ & 1502 & 12 & 332 & 33 & 14 & 489 & 18 & 0 \\
\hline $\begin{array}{l}\text { Suma dla } \\
96 \text { osób }\end{array}$ & 1802 & 14 & 388 & 38 & 18 & 589 & 24 & 0 \\
\hline
\end{tabular}

Leksykalne formy grzecznościowe 'prosić' (請 qüng, 麻煩你 máfan nǔ, 可不可以 kěbù kèyì) są bezpośrednim działaniem językowym i jako takie wpisują się w tzw. grzeczność pozytywną. Nieobecne lub mało obecne w wypowiedziach, potwierdzają przewagę narzędzi językowych realizujących grzeczność negatywną. Wtrącenia 我觉得 wǒ juédé 'myślę, że' użyto łącznie 311 razy (w 303 wypowiedziach), wyrażenia 好像 hăoxiàng 'wydaje się, że' użyto 26 razy, wtrącenia 可能 kěnéng 'chyba' - 51 razy. Czasem w jednym zdaniu pojawia się kilka wtrąceń. Połączenie wtrącenia i innego środka językowego w wypowiedzi dodatkowo zmniejsza siłę wypowiedzi, np. 好像 hăoxiàng 'wydaje się, że' razem z przysłówkiem osłabiającym 有点 yǒudiăn 'trochę' lub końcówką pytającą o znaczeniu 'prawda?', ‘czyż nie?', np. 是不是 shì bú shì. Końcówki pytające pojawiają się w badanym materiale 11 razy: 好不好 hăo bù hăo - 4 razy, 对不对 duì bú duì -4 razy, 是不是 shì bú shì -3 razy.

$\mathrm{W}$ analizowanym materiale główną rolę $\mathrm{w}$ wyrażaniu dystansu do odbiorcy przez młode kobiety odgrywają partykuły modalne (589 użyć), których wyłoniono 17 (tabela 5), co świadczy o bogactwie tych środków w języku. Najpopularniejsze wśród nich są 吧 $b a(185)$ i (啊 $a$ 153).

Analizowane wypowiedzi nie pozwalają wnioskować o grzeczności negatywnej wyrażanej przez formułowanie i odrzucanie komplementów. Warto też zauważyć, że w tak obszernym materiale językowym brakuje - silnie utożsamianego z uniżoną postawą nadawcy - zaimka osobowego 人家 rénjia. 
W zgromadzonym materiale językowym zaobserwowano w sumie 1427 przykładów użycia środków językowych nadających wypowiedzi łagodny i/lub emocjonalny charakter (tabela 2). Najliczniej reprezentowane okazują się przysłówki stopnia (659) i przymiotniki puste (192). Znaczące użycie wykazują wykrzykniki (ekspresywne ze swej istoty - 26 różnych form, 169 wystąpień), reduplikacja (178) i przysłówek 真的 zhēnde 'naprawdę' (167) oraz zaimki wzmacniające 这么 zhème lub 那么 nàme 'tak bardzo’ (54). Deminutywy wprowadzające poufałość mają niewielkie znaczenie (8 wystąpień). Realizacja na antenie telewizyjnej uzasadnia brak eufemizmów.

Trzy najaktywniejsze uczestniczki wyrażały łagodność i język emocji odpowiednio 79 (A), 87 (B) i 80 (C) razy, z wykorzystaniem przysłówków stopnia - 39 (A), 38 (B) i 35 razy (C) i pustych przymiotników - 13 (A), 11 (B) i 11 razy (C). Wykrzykniki zostały przez te osoby użyte 6 (A), 14 (B) i 4 razy (C), a reduplikacja - 9 (A), 13 (B) i 17 razy (C). Przysłówek 真的 zhēnde 'naprawdę', wzmacniający wiarygodność wypowiedzi, został użyty 9 razy przez uczestniczkę (A), 9 przez (B) i 8 razy przez (C). Zaimki wzmacniające 这么 zhème lub 那么 nàme 'tak bardzo' pojawiły się w ich wypowiedziach dwukrotnie (A), raz (B) i cztery razy (C). Za symboliczną należy uznać liczbę deminutywów nacechowanych emocjami, użytych przez każdą z uczestniczek tylko jeden raz.

\section{Tabela 2}

Środki językowe w wyrażaniu tagodności, emocji i ekspresji

\begin{tabular}{|c|c|c|c|c|c|c|c|c|c|}
\hline \multirow{2}{*}{$\begin{array}{l}\text { Kod } \\
\text { uczest- } \\
\text { niczki }\end{array}$} & \multirow{2}{*}{$\begin{array}{l}\text { Liczba } \\
\text { wypo- } \\
\text { wiedzi }\end{array}$} & \multicolumn{8}{|c|}{$\begin{array}{l}\text { Forma wyrazu nadająca wypowiedzi lagodny, emocjonalny charakter - } \\
\text { obserwacje }\end{array}$} \\
\hline & & $\begin{array}{l}\text { eufe- } \\
\text { mizmy }\end{array}$ & $\begin{array}{l}\text { puste } \\
\text { przy- } \\
\text { miotniki }\end{array}$ & $\begin{array}{l}\text { zaimki } \\
\text { wzmac- } \\
\text { niające }\end{array}$ & $\begin{array}{l}\text { przy- } \\
\text { słówki } \\
\text { stopnia }\end{array}$ & $\begin{array}{l}\text { wy- } \\
\text { krzyk- } \\
\text { niki }\end{array}$ & $\begin{array}{l}\text { redupli- } \\
\text { kacja }\end{array}$ & $\begin{array}{l}\text { demi- } \\
\text { nutywy }\end{array}$ & $\begin{array}{l}\text { zapewnie- } \\
\text { nie o wia- } \\
\text { rygodności }\end{array}$ \\
\hline (A) & 103 & 0 & 13 & 2 & 39 & 6 & 9 & 1 & 9 \\
\hline (B) & 102 & 0 & 11 & 1 & 38 & 14 & 13 & 1 & 9 \\
\hline (C) & 95 & 0 & 11 & 4 & 35 & 4 & 17 & 1 & 8 \\
\hline $\begin{array}{l}93 \text { po- } \\
\text { zostałe } \\
\text { uczest- } \\
\text { niczki }\end{array}$ & 1502 & 0 & 157 & 47 & 547 & 145 & 139 & 5 & 141 \\
\hline $\begin{array}{l}\text { Suma } \\
\text { dla } \\
96 \text { osób }\end{array}$ & 1802 & 0 & 192 & 54 & 659 & 169 & 178 & 8 & 167 \\
\hline
\end{tabular}

W ekspresywności języka mieszczą się - przypisywane kobietom - łagodny charakter wypowiedzi i emocjonalność. Wpisuje się w nie brak przekleństw, chociaż w badanym materiale nie ma też eufemizmów. Funkcję ekspresywną przejęły tu wykrzykniki komunikujące silne emocje lub reakcje. Odnotowano 26 różnych wykrzykników (zob. tabela 6), 
niektóre o podobnym znaczeniu i takim samym morfemie głównym (np. 天呐 tiānnà $\mathrm{i}$ 天哪 tiānnă 'o Boże', 我的妈呀 wǒdemāya i 我的个妈呀 wǒdegemāya 'o mamo'). Najczęściej używanym (42 razy) wykrzyknikiem jest 哇 wā.

Do ekspresywności wypowiedzi mocno przyczyniają się przymiotniki puste (zaobserwowano ich 9 w 192 użyciach; zob. tabela 7) w konstrukcji z przysłówkami stopnia (15 w 659 użyciach; zob. tabela 8). Imponująca frekwencyjność 好 hăo (252), 太 tài (111) oraz 特别 tèbié (85) 'bardzo' / 'szczególnie' w wypowiedziach kobiet nie dziwi, ponieważ to podstawowe przysłówki tego typu w języku. Do kategorii przysłówków stopnia nie zostały wliczone przysłówki osłabiające siłę wypowiedzi, omówione wcześniej jako środki grzeczności negatywnej, oraz przysłówek zapewniający o wiarygodności 真的 zhēnde 'naprawdę'. Niewątpliwie jednak ten akurat przysłówek podnosi ekspresywność językowych działań uczestniczek, podobnie jak zaimki wzmacniające 这么 zhème $\mathrm{i}$ 那么 nàme ‘tak bardzo', zaobserwowane w materiale 54 razy. Funkcję wysoce ekspresywną pełni w języku chińskim powszechnie używany zabieg reduplikacji, stosowany wobec wyrazów z różnych klas gramatycznych w zakresie leksykalnym, morfologicznym (gdy powstają konstrukcje wyrazowe) lub składniowym. W analizowanych wypowiedziach reduplikacja pojawiła się 178 razy. Na uwagę zasługują emocjonalne, bardzo nieformalne, aż trzykrotne powtórzenia czasownika posiłkowego w konstrukcji orzeczenia złożonego 喜欢 xǐhuān + V dla każdego z trzech czasowników osobno 'lubię..., i lubię..., i lubię...', trzykrotna reduplikacja grupy przymiotnika z przysłówkiem 很多 hěn dūo 'bardzo liczny' czy trzykrotne powtórzenie prostego czasownik 听 tīng 'słucham i słucham'. Takie zrealizowanie reduplikacji wykracza poza ramy gramatyczne standardowego języka.

Deminutiwy nacechowane uczuciami, nielicznie zaobserwowane w badanym materiale, pełnią tu w mniejszym stopniu funkcję ekspresywną, a w większym - służą budowaniu więzi emocjonalnej i bliskości. Co ciekawe, z jakościowego punktu widzenia nie są to morfologiczne zdrobnienia, a jedynie - zwroty adresatywne. Rzeczowniki 宝宝 băobăo 'skarb/skarbie', 胖虎 pàng hǔ 'tygrys/tygrysku', 妈咪 $m \bar{a} m \bar{\imath}$ ' 'mamusia/mamusiu’, kierowane do współuczestniczek programu, wpisują się w „użycie skróconej lub zdrobniałej formy imienia [...] [jako] wyraz[u] sympatii i nieformalnej więzi łączącej rozmówców" (Kostro i Wróblewska-Pawlak 2013, 162).

W zakresie ujawnionych zjawisk fonetycznych i prozodycznych (375 wystąpień) najliczniej reprezentowane okazało się naśladowanie wymowy i zachowania dziecka (97 razy), a na drugim miejscu - przedłużanie wygłosu (66 razy). Maniera 女国音 nüguóyīn pojawiła się 62 razy, a łączone z sajiao zjawisko 娃娃音 wáwayinn- 61 razy. Nieco mniej wystąpień mają intonacja wznosząca (47) i wariant wymowy [v] (40 razy). Bez znaczenia są dwa przypadki synkopy i substytucji.

Na uwagę zasługuje fakt dużej dysproporcji użycia tych środków wśród trzech zwyciężczyń programu. U osoby (A) zaobserwowano jedynie sporadyczne (po trzy razy) użycie wymowy naśladującej zachowanie dziecka, jego bezradność i sposób mówienia oraz intonacji wznoszącej w wypowiedzi. Uczestniczka (B) 35 razy używa takiej artykulacji i prozodii. Dominują u niej naśladowanie dziecka (12) i przedłużone wygłosy (13), ale obecne są także intonacja wznosząca (5) i naśladowanie wysokiego 
rejestru małego dziecka (4 razy). Raz pojawia się wariant [0]. Wyraźnie najbardziej ekspresywna na płaszczyźnie artykulacji i intonacji w gronie zwyciężczyń okazała się uczestniczka (C) - 40 potwierdzeń. To u niej pojawiło się najwięcej (bo aż 9) wypowiedzi o wznoszącej intonacji. Uwagę zwraca silnie reprezentowana maniera 女国音 nüguóyin (11 wystąpień). Naśladowanie wymowy dziecka wystąpiło 8 razy, przedłużenie wygłosu -6 razy, wysoki rejestr -4 razy, a wariant [0] - tylko dwa razy (zob. tabela 3).

Tabela 3

Środki językowe fonetyczne i prozodyczne charakterystyczne dla języka kobiet

\begin{tabular}{|c|c|c|c|c|c|c|c|c|}
\hline \multirow{2}{*}{$\begin{array}{l}\text { Kod } \\
\text { uczest- } \\
\text { niczki }\end{array}$} & \multirow{2}{*}{$\begin{array}{l}\text { Liczba } \\
\text { wypo- } \\
\text { wiedzi }\end{array}$} & \multicolumn{7}{|c|}{ Fonetyka i prozodia - obserwacje } \\
\hline & & $\begin{array}{l}\text { maniera } \\
\text { wariant } \\
{[v]}\end{array}$ & $\begin{array}{l}\text { maniera } \\
\text { 女国音 } \\
\text { nüguóyinn }\end{array}$ & $\begin{array}{l}\text { 娃娃音 } \\
\text { wáwayin }\end{array}$ & $\begin{array}{l}\text { prze- } \\
\text { dłużone } \\
\text { wygłosy }\end{array}$ & $\begin{array}{l}\text { synko- } \\
\text { pa - utrata } \\
\text { samogłos- } \\
\text { ki }\end{array}$ & $\begin{array}{l}\text { naśla- } \\
\text { dowanie } \\
\text { dziecka }\end{array}$ & $\begin{array}{l}\text { intonacja } \\
\text { wzno- } \\
\text { sząca }\end{array}$ \\
\hline (A) & 103 & 0 & 0 & 0 & 0 & 0 & 3 & 3 \\
\hline (B) & 102 & 1 & 0 & 4 & 13 & 0 & 12 & 5 \\
\hline (C) & 95 & 2 & 11 & 4 & 6 & 0 & 8 & 9 \\
\hline $\begin{array}{l}93 \\
\text { pozostałe } \\
\text { uczest- } \\
\text { niczki }\end{array}$ & 1502 & 37 & 51 & 53 & 47 & 2 & 74 & 30 \\
\hline $\begin{array}{l}\text { Suma dla } \\
96 \text { osób }\end{array}$ & 1802 & 40 & 62 & 61 & 66 & 2 & 97 & 47 \\
\hline
\end{tabular}

Z myślą o podsumowaniu zagadnień dotyczących sposobu wypowiedzi i artykulacji w badanym materiale trzeba powiedzieć, że stosowane środki fonetyczne łączą się w zespół cech przypisywanych stylowi sajiao. Wynikają one w dużym stopniu z dziecinnego zachowania werbalnego i z dziecięcej artykulacji o wysokim rejestrze. Jako równie silnie reprezentowaną cechę należy dodać przedłużanie wygłosów. Warianty wymowy [v], [ts], [tsh], [s] stanowią $27,2 \%$ obserwacji dotyczących fonetyki i prozodii, należy je zatem uznać za znaczące zjawisko fonetyczne w kręgu młodych kobiet. Tylko dwukrotnie w całym materiale językowym zaobserwowano zjawisko zmiany brzmienia wygłosów o charakterze synkopy - utraty samogłoski [e] przy równoczesnej substytucji [d3] głoską [t6] oraz utraconego [e] dyftongiem [ou] (połączenie 这样 zhè yàng w jiàng, zmiana 可 kě w kǒu).

Gdy do wypowiedzi o wznoszącej intonacji każdej z uczestniczek dodać wypowiedzi ze zdaniowymi partykułami modalnymi, z założenia wymawianymi w tzw. lekkim zredukowanym tonie, to zyskujemy bardzo wyrównaną reprezentację wznoszącej intonacji u zwyciężczyń: uczestniczki (A) - 40 razy dla 103 jej wypowiedzi, (B) 39 razy dla 102 wypowiedzi i (C) 38 razy dla 95 wypowiedzi. Stanowi to $38,8 \%$ u (A), $38,2 \%$ u (B) i 40\% u uczestniczki (C), a dla wszystkich wypowiedzi nacechowanych intonacją wznoszącą - 35,3\%. 


\section{PODSUMOWANIE}

Wyniki analizy środków językowych w języku chińskim są głosem w dyskusji nad specyfiką wypowiedzi kobiet, pozwalającą działać językowo nieagresywnie, a jednak skutecznie. Nie odnotowano użycia wyrazu 人家 rénjia jako zaimka pierwszej osoby, jak można by się spodziewać po ustaleniach Shi $(1984,219)$, Farris $(1988,291)$ i Chan $(1998,43)$. Nie zaobserwowano także wykrzykników 哼 hēng, 喝 he, 咦 yí, 吥 pēi, wskazanych przez Qi i Zhang $(2009,66)$. Nie pokrywa się również do końca zasób partykuł modalnych proponowanych przez Ma $(2009,59)$. Uwagę zwraca fakt, że przysłówek 蛮 mán, który Zeng $(2007,65-68)$ nazwał dialektalnym i przypisał mężczyznom, pojawia się także u kobiet. Potwierdziły się natomiast - zależna od pozycji w zdaniu - wielokategorialność wyrazów 啊 $\bar{a}$, 哦 $o ́$ i 呃 $e$ (partykuła modalna / wykrzyknik), opisana przez Chao $(1968,817)$ oraz absolutna większość środków wskazanych przez badaczy. Potwierdzono dotychczasowe założenia odnoszące się zarówno do zasobów językowych, jak i do ich roli w działaniu językowym i interpretacji w socjolekcie chińskich kobiet.

Ilościowa i jakościowa analiza wypowiedzi uczestniczek programu, ,创造101” Chuàngzào101 przez pryzmat idiolektów trzech zwyciężczyń programu pozwoliła wskazać użycie środków językowych w perspektywie indywidualnej i w ujęciu grupy młodych kobiet. Uczestniczka (A) najmniej spośród tych trzech kobiet korzystała z samych narzędzi fonetycznych i prozodycznych. Jej wypowiedzi okazały się najsilniej nacechowane środkami wpisującymi się w grzeczność negatywną. Wypowiedzi osoby (B) charakteryzują się największą ekspresywnością, przy równoczesnym stosunkowo wyraźnym użyciu środków grzeczności negatywnej i stylu sajiao (liczne użycie partykuł modalnych, naśladowanie wypowiedzi dziecka i przedłużanie wygłosów). W wypowiedziach uczestniczki (C) obecnych jest najwięcej zdarzeń fonetycznych i prozodycznych, zarówno związanych z manierą artykulacji, jak i ze stylem sajiao. Jej emocjonalizm stosunkowo często realizuje się w reduplikacji, natomiast spośród badanych kobiet to właśnie (C) najmniej korzysta z zabiegów językowych wpływających na grzeczność negatywną.

W materiale obejmującym 1802 wypowiedzi, spośród 2859 zaobserwowanych wystąpień środków językowych charakterystycznych dla kobiet, najchętniej używane w wypowiedziach były przysłówki intensywności - 23,01\% obserwacji. Równie wysoko wśród środków językowych używanych przez kobiety plasują się zdaniowe partykuły modalne (20,6\% wskazań), generujące wznoszącą intonację zdania, która osobno (poza zdaniami z partykułą) stanowi 1,6\% zaobserwowanych zdarzeń. Mimo wyraźnie obecnych cech fonetycznych i prozodycznych (375 wystąpień, co daje 13,1\%), charakteryzujących wypowiedzi młodych kobiet, to środki językowe wpływające na lagodny i emocjonalny charakter wypowiedzi (1427 obserwacji - 49,9\%) i - w drugiej kolejności - na grzeczność negatywną $(1070$ - 37,4\%) są najliczniej reprezentowane w badanym materiale językowym. Kobiecy socjolekt chiński zatem wyraża emocjonalność silniej niż grzeczność negatywną. 


\section{ANEKS}

Tabela 4

Czas antenowy odcinków programu

\begin{tabular}{|ll|}
\hline Odcinek & Czas \\
\hline odc. 1 & $2: 04: 12$ \\
\hline odc. 2 & $2: 26: 29$ \\
\hline odc. 3 & $3: 13: 47$ \\
\hline odc. 4 & $2: 38: 55$ \\
\hline odc. 5 & $1: 52: 58$ \\
\hline odc. 6 & $3: 16: 25$ \\
\hline odc. 7 & $2: 16: 38$ \\
\hline odc. 8 & $2: 48: 32$ \\
\hline odc. 9 & $1: 57: 13$ \\
\hline odc. 10 & $4: 17: 01$ \\
\hline Suma & $26: 52: 10$ \\
\hline
\end{tabular}

Tabela 5

Partykuty modalne

\begin{tabular}{|l|l|}
\hline Partykula & Wystąpienia \\
\hline 吧 $b a$ & 185 \\
\hline 啊 $a$ & 153 \\
\hline 嘛 $m a$ & 64 \\
\hline 呀 $y a$ & 63 \\
\hline 呢 $n e$ & 51 \\
\hline 啦 $l a$ & 24 \\
\hline 哦 $o$ & 18 \\
\hline 呃 $e$ & 7 \\
\hline 呗 $b e i$ & 5 \\
\hline 喽 $l o u$ & 5 \\
\hline 耶 $y e$ & 3 \\
\hline 哪 $n a$ & 3 \\
\hline 呐 $n a$ & 2 \\
\hline 嘞 $l e i$ & 2 \\
\hline 吆 $y o$ & 2 \\
\hline 唉 $a i$ & 1 \\
\hline 呦 $y o u$ & 1 \\
\hline Suma & 589 \\
\hline
\end{tabular}


Tabela 6

Wykrzykniki

\begin{tabular}{|c|c|}
\hline Wykrzyknik & Wystąpienia \\
\hline 哇 $w \bar{a}$ & 42 \\
\hline 天呐 tiānnà & 28 \\
\hline 天哪 tiānnă & 11 \\
\hline 妈呀 $m \bar{a} y a$ & 14 \\
\hline 我的天呐 wǒdetiānnà & 11 \\
\hline 我的 天哪 wǒdetiānnă & 2 \\
\hline 哎呀 $\bar{a} i y \bar{a}$ & 12 \\
\hline 我的妈呀 wǒdemāya & 11 \\
\hline 啊 $\bar{a}$ & 7 \\
\hline 唉 $\bar{a} i$ & 7 \\
\hline 哦 $\dot{c}$ & 4 \\
\hline 我的妈 wǒdemā & 3 \\
\hline 我的天 wǒdetiān & 2 \\
\hline 哇塞 wasāi & 2 \\
\hline 啊呀 $\bar{a} y \bar{a}$ & 2 \\
\hline 唉呦 $\bar{a} i y \bar{o} u$ & 1 \\
\hline 䒝呦 āiyōu & 1 \\
\hline 诶呀 èiya & 1 \\
\hline 䒝哟喂 āiyōwèi & 1 \\
\hline 哇哦 $w a$ 'ó & 1 \\
\hline 嘿 hēi & 1 \\
\hline 吃 $\dot{e}$ & 1 \\
\hline 欸 $\breve{a} i$ & 1 \\
\hline 喂wèi & 1 \\
\hline 妈妈呀 māmaya & 1 \\
\hline 我的个妈呀 wǒdegemāya & 1 \\
\hline Suma & 169 \\
\hline
\end{tabular}


Tabela 7

Przymiotniki puste

\begin{tabular}{|l|l|}
\hline Przymiotnik & Wystąpienia \\
\hline 漂亮 piàoliang 'fadny' & 8 \\
\hline 好看 hăokàn 'ładny' & 26 \\
\hline 帅 shuài 'fajny/przystojny' & 25 \\
\hline 可爱 kě’’ài ‘uroczy' & 38 \\
\hline 酷 kù 'fajny' & 10 \\
\hline 厉害 lìhài 'fajny' & 23 \\
\hline 美 měi 'piękny' & 18 \\
\hline 棒 bàng 'super' & 41 \\
\hline 爽 shuăng 'fajny' & 3 \\
\hline Suma & 192 \\
\hline
\end{tabular}

Tabela 8

Przysłówki stopnia/intensywności

\begin{tabular}{|l|l|}
\hline Przyslówek & Wystąpienia \\
\hline 好 hăo & 252 \\
\hline 太 tài & 111 \\
\hline 特别 tèbié & 85 \\
\hline 挺 ť̌ng & 50 \\
\hline 最 zuì & 48 \\
\hline 非常 fēicháng & 45 \\
\hline 超 chāo & 19 \\
\hline 比较 bǐjiào & 18 \\
\hline 蛮 mán & 11 \\
\hline 真 zhēn & 7 \\
\hline 超级 chāojí & 5 \\
\hline 可 kě & 5 \\
\hline 格外 géwài & 1 \\
\hline 特 tè & 1 \\
\hline 尤其 yóuqi & 1 \\
\hline Suma & 659 \\
\hline
\end{tabular}




\section{BIBLIOGRAFIA}

Awdiejew, A., i G. Habrajska. 2006. Wprowadzenie do gramatyki komunikacyjnej. T. 2. Łask: Leksem.

Bartwicka, H. 2007. „Gatunki mowy a język kobiet (na przykładzie języka rosyjskiego)”. Linguistica Bidgostiana 4: 15-24.

Brown, P., i S. Levinson. 1988. Politeness: Some universals in language usage. Cambridge: Cambridge University Press.

Cao, Y. 1986. „Běijīng huà yǔyīn zhōnglǐ de xìngbié chāyì [Gender Differences in the Pronunciation of Beijing Dialect]”. Hànyǔ xuéxí 6: 31.

Chan, M. 1998. „Gender differences in the Chinese language: a preliminary report”. W NACCL-9. 2, red. H. Lin. GSIL Publications, University of Southern California, 35-52. https://www.semanticscholar.org/ paper/GENDER-DIFFERENCES-IN-THE-CHINESE-LANGUAGE-\%3A-A-Chan/f47478715581b7f3f6ece548a123218e7aba74f9 (15 lutego 2021).

Chan, M., i L. Yuhan. 2019. „Chinese language and gender research”. W The Routledge Handbook of Chinese Applied Linguistics. New York: Routledge, 165-181. https://www.routledgehandbooks.com/ doi/10.4324/9781315625157-12 (15 lutego 2021).

Chao, Y.R. 1968. A Grammar of Spoken Chinese. Pekin: The Commercial Press.

Chen, F. i in. 1992. „Reduplication in Mandarin Chinese: Their Formation Rules, Syntactic Behavior, and ICG Representation". W The Fifth ROC Computational Linguistics Conference at Taipei, Taiwan. Taiwan: 217-233.

Ding, F. 2002. „Hànyǔ qǔngqiú yányǔ xíngwéi zhōng dì xìngbié chāyì. [Gender Differences in the Speech Act in Chinese Requests]". Xī'ān wàiguóyǔ xuéyuàn xuébào 10 (1): 46-50. https://wenku.baidu.com/ view/c81f41ed4afe04a1b071de50.html (15 lutego 2021).

Farris, C.S. 1988. „Gender and Grammar in Chinese: With Implications for Language Universals”. Modern China 14 (3): 27-308.

Farris, C.S. 1991. „The Gender of Child Discourse: Same-Sex Peer Socialization Through Language Use in a Taiwanese Preschool". Journal of Linguistic Anthropology 1 (2): 198-224. https://www.jstor.org/ stable/43102129 (15 lutego 2021).

Grabias, S. 2019. Język w zachowaniach społecznych. Podstawy socjolingwistyki i logopedii. Lublin: Wydawnictwo Uniwersytetu Marii Curie-Skłodowskiej.

Hardeman, K. 2013. Gender and Second Language Style: American Learner Perceptions and Use of Mandarin Sajiao. Honolulu: University of Hawai'i at Mānoa. (PhD Thesis). http://www.ling.hawaii.edu/ graduate/Dissertations/KateHardemanFinal.pdf (15 lutego 2021).

Hu, H.C. 1944. „The Chinese Concept of Face”. American Anthropologist 46 (1): 45-64.

Jarosz, B. 2013. „O zasięgu słownictwa socjolektalnego w XXI wieku”. Białostockie Archiwum Językowe 13: $97-116$.

Jiang, L. 2007. „Wěiwăn yǔ yǔ xìngbié chāyì - nánjīng bùfèn gāoxiào wěiwăn yǔ shřyòng qíngkuàng diàochá [Euphemisms and Gender Differences - A survey of euphemism usage in some colleges and universities in Nanjing]". Yǔyán yingyòng yánjiū 2: 57-58. http://www.cqvip.com/qk/87478a/2007002/23879809. html (15 lutego 2021).

Kostro, M., i K. Wróblewska-Pawlak. 2013. „Formy adresatywne jako środek jawnej i ukrytej deprecjacji kobiet polityków w polskim dyskursie polityczno-medialnym". Tekst $i$ dyskurs - text und diskurs 6: 153-168. http://tekst-dyskurs.eu/images/pdf/zeszyt_6/Kostro.pdf (15 lutego 2021). 
Lakoff, R. 1973. „Language and Woman's Place”. Language in Society 2 (1): 45-80. https://www.cambridge. org/core/journals/language-in-society/article/language-and-womans-place/F66DB3D1BB878CDD68B9A79A25B67DE6 (15 lutego 2021).

Li, Ch., i S. Thompson. 1989. Mandarin Chinese. A Functional Reference Grammar. London: University of California Press.

Lin, H.H. 2005. Contextualizing Linguistic Politeness in Chinese - a Socio-pragmatic Approach with Examples From Persuasive Sales Talk in Taiwan Mandarin. Ohio State University. (PhD Thesis). https:// www.semanticscholar.org/paper/Contextualizing-linguistic-politeness-in-Chinese-a-Lin/e3be72d1b0dca6b00dae3af1404536d689044068 (15 lutego 2021).

Liu, Ch.J. 2005. Gender Differences in TV Talk Shows in Taiwan: A Sociolinguistic Study. Taipei: National Taiwan Normal University. (MA Thesis). http://rportal.lib.ntnu.edu.tw/handle/20.500.12235/97301 (15 lutego 2021).

Liu, Y. i in. 1996. Shíyòng xiàndài hànyǔ yŭfă [Modern Chinese Grammar]. Taipei: Shī dà shū yuàn yǒuxiàn gōngsī.

Ma, Y. 2009. „Hànyǔ gōngwéi yǔ zhòng de xìngbié yǔyán shízhèng yánjiū [An Empirical Study of Compliments in Chinese Gender Language]". Shāngluò xuéyuàn xuébào 23 (5): 57-62. https://wap.cnki.net/ touch/web/Journal/Article/SLSF200905017.html (15 lutego 2021).

Niewdana, L. 2011. „Osobowe relacje (guānxi) w chińskim biznesie”. W Zrozumieć Chińczyków. Kulturowe kody społeczności chińskich, red. E. Zajdler. Warszawa: Wydawnictwo Akademickie Dialog, 205-236.

Pan, F. 2015. „Hànyǔ yǔyán zhōng de xìngbié qíshì xiànxiàn [Sexism in the Chinese language]”. Ānhuī wénxué 10: 78-79. https://www.cnki.com.cn/Article/CJFDTotal-AHWA201510039.htm (15 lutego 2021).

Qi, S., i Z. Jinliang. 2009. „Găntàn cíyǔ dì xìngbié chāyì yánjiū [Study on Gender Differences in Exclamatory Words]”. Yǔyán yingyòng yánjiū 12: 64-66. https://www.airitilibrary.com/Publication/alDetailedMesh?docid=10088024-200912-201001270023-201001270023-64-66 (15 lutego 2021).

Shi, Y. 1984. „Cóng shèhuì yǔyán xué guāndiăn tàntăo zhōngwén nánnŭ liăngxìng yǔyán de chāyì [Discussing the language differences in Chinese between men and women from the perspective of sociolinguistics]". Jiàoxué yǔ yánjiū 6: 207-228. https://www.airitilibrary.com/Publication/alDetailedMesh?DocID=10163026-198405-201307240028-201307240028-207-228 (15 lutego 2021).

Sun, R. 2012. Xìngbié yǔ yǔyán [Gender and Language]. Pekin: Kēxué chūbăn shè.

Tannen, D. 1999. Ty nic nie rozumiesz! Kobieta i mężczyzna w rozmowie. Poznań: Zysk i S-ka.

Tseng, Ch.Ch. 2008. Huáyǔ yǔyin zīliào kù jí shùwèi xuéxi yìngyòng [Chinese Voice Database and Digital Learning Application]. Taipei: Xīn xué lín.

Wamsley, J. 2019. „Gendered Usage of Sentence-Final Particles in Mandarin Chinese”. ULC Working Papers 1: 1-20. https://scholarworks.iu.edu/journals/index.php/iulcwp/article/view/27100 (15 lutego 2021).

Wang, G. 2013. „Nǔxìng yǔyán de fềnggé tèdiăn [Stylistic Features of Female Language]”. Nèiménggǔ diàn dàxué kān 3: 40-56. http://d.wanfangdata.com.cn/periodical/nmgddxk201303014 (15 lutego 2021).

Wesołowski, Z. 2011. „Konfucjańskie podstawy porządku społecznego i zjawisko «twarzy»”. W Zrozumieć Chińczyków. Kulturowe kody społeczności chińskich, red. E. Zajdler. Warszawa: Wydawnictwo Akademickie Dialog, 175-201.

Wiertlewski, S. 1995. Pytania bez odpowiedzi. Pytania jako pośrednie akty mowy. Poznań: Sorus.

Yueh, H.I. 2012. The tactic of the Weak: A critical analysis of feminine persuasion in Taiwan. Iowa: University of Iowa. (PhD Thesis). https://ir.uiowa.edu/cgi/viewcontent.cgi?article=3360\&context=etd (15 lutego 2021). 
Yueh, H.I. 2013. „Body Performance in Gendered Language. Deconstructing the Mandarin Term Sajiao in the Cultural Context of Taiwan". Journal of Theories and Research in Education 8 (1): 160-182. https:// rpd.unibo.it/article/view/3777 (15 lutego 2021).

Zeng, W. 2007. „Kǒuyǔ zhòng chéngdù fùcí shǐyòng de xìngbié chāyì [Gender Differences in the Use of Adverbs of Degree in Spoken Language]". Xiūcíxuéxí 3: 65-70. http://www.cqvip.com/qk/81623x/2007003/24583582. html (15 lutego 2021).

Zhao, R. 2003. Yǔyán yǔ xìngbié. Kǒnyǔ de shèhuì yǔyán xué yánjiū [Language and gender. Sociolinguistic Research on Spoken Language]. Shanghai: Shànghăi wàiyǔ jiàoyù chūbăn shè.

\title{
WYKAZ ŹRÓDEL
}

Platforma 腾讯视频 Téngxùn shipin (ang. Tencent Video), https://www.youtube.com/channel/UCQatgKoA7lylp_UzvsLCgcw (15 lutego 2021).

\section{Linguistic Features in Mandarin Chinese as Feminine Markers in Informal Communication}

Keywords: Mandarin Chinese, female sociolect, women's linguistic behaviour, sajiao.

\begin{abstract}
The paper deals with a correlation between the linguistic features of Mandarin Chinese and the language activities of young female participants in a television show broadcast on the Internet. The women's sociolect and the characteristics of the sajiao style are analysed on the basis of their 1802 informal utterances recorded on the show. The paper explores the way in which lexical and phonetic features express femininity and contribute to the women's persuasive talk. The formal markers of the language used by female native speakers communicate politeness, emotions and gentleness and at the same time acknowledge their position of subordination within society. The study begins with an introduction into the pragmatics of culture-driven language activity and moves on to outline the current knowledge of the peculiarities of the Chinese language used by Chinese women. Drawing on earlier discussions, a compilation of linguistic features is employed as an analytical tool. The particular words and expressions as well as pronunciation features are discussed. Not all linguistic features of Mandarin Chinese discussed in previous studies are confirmed in the utterances under study. Those which add significant expressive meaning and gentleness into an utterance dominate in the study over the sajiao style, the phonetic and prosodic features typical for a babyish form of persuasion. As evidenced by a quantitative and qualitative analysis, the utterances in question abound in emotions, in wavering opinions that put the speaker in a position inferior to that of the addressee, and in instances of speaking in a manner typical of children.
\end{abstract}

